\title{
Kinetic parameters of ruminal degradation in vitro with combinations of exogenous enzymes in diets of production systems simulated ${ }^{1}$
}

\author{
Parâmetros cinéticos de degradação ruminal in vitro com combinações de enzimas \\ exógenas em dietas de sistemas de produção simulados
}

\author{
FREIRIA, Lucien Bissi $\mathrm{da}^{2}$; ZERVOUDAKIS, Joanis Tilemahos ${ }^{2}$; PAULA, Nelcino \\ Francisco de ${ }^{2}$; CABRAL, Luciano da Sival ${ }^{2}$; BOAS, Yasmim Rodrigues Vilas ${ }^{3}$; \\ SILVA, Pedro Ivo Jose Lopes da Rosa e $\mathrm{e}^{2}$, MELO, Alan Carlos Barbosa ${ }^{4}$; POSSAMAI, \\ Adriano Jorge $^{2}$
}

\footnotetext{
${ }^{1}$ Universidade Federal de Mato Grosso, Cuiabá, Brasil, trabalho financiado pela CAPES.

${ }^{2}$ Universidade Federal de Mato Grosso, Faculdade de Agronomia e Zootecnia, Programa de PósGraduação em Ciência Animal, Cuiabá, Mato Grosso, Brasil.

${ }^{3}$ Universidade Federal de Mato Grosso, Faculdade de Agronomia e Zootecnia, Cuiabá, Mato Grosso, Brasil.

${ }^{4}$ Universidade Estadual Paulista, Programa de Pós-Graduação em Ciência e Tecnologia Animal, Dracena, São Paulo, Brasil.

*Endereço para correspondência: lucienbissi@hotmail.com
}

\section{SUMMARY}

This study evaluated the effects of eight combinations of three exogenous enzymes with fibrolytic activity (FIB), amylolytic activity (AMZ), and proteolytic activity (PRO) on the accumulated gas production (PG) and kinetic parameters in simulated fermentations in two diet production systems using the in vitro gas production technique. In experiment 1 , ruminal fluid was obtained from two Santa Ines sheep, cannulated in the rumen, kept in a feedlot and fed a diet containing a roughage:concentrate ratio of 20:80. In experiment 2, the ruminal fluid was obtained from two Santa Ines sheep, cannulated in the rumen, and kept on pasture (Brachiaria brizantha cv. Marandu). The accumulated gas production was measured during a 96-hour incubation, measured at 18 different time points. After incubation, the $\mathrm{pH}$, dry matter degradability, organic matter in vitro digestibility, digestibility of neutral detergent insoluble fiber, metabolizable energy, partitioning factor, gas yield, short chain fatty acids and microbial protein production were determined. In the in vitro fermentation using the feedlot diet, the increased use of fibrolytic enzymes increased PG and improved the profile characteristics and kinetic parameters of the fermentation, regardless of the combination with other enzymes. In the in vitro fermentation using the forage diet, increased fibrolytic enzymes also increased PG, with improvements in the kinetic parameters and the profile of the fermentation, independent of the use of the other enzymes. The addition only of fibrolytic enzymes has major potential to optimize the use of feedlot diets as well of forage in ruminant feed.

Keywords: amylolytic, feedlot, fibrolytic, forage, proteolytic

\section{RESUMO}

Objetivou-se avaliar oito combinações entre três enzimas exógenas fibrolíticas (FIB), amilolíticas (AMZ), e proteolíticas (PRO), sobre a produção acumulada de gás (PG), parâmetros cinéticos e perfil da fermentação simulando dietas de dois sistemas de produção através da técnica de produção de gás in vitro. No experimento 1 , o líquido ruminal foi obtido de dois ovinos da raça Santa Inês, canulados no rúmen, mantidos em confinamento, alimentados com dieta com relação volumoso:concentrado 20:80. No experimento 2, o líquido ruminal foi obtido de dois ovinos da raça Santa Inês, canulados no rúmen, mantidos no pasto (Brachiaria brizantha 
cv. Marandu). A produção de gás acumulada foi obtida em 96 h de incubação, mensurada em 18 horários. Ao final da incubação determinaramse o $\mathrm{pH}$, degradabilidade da matéria seca, digestibilidade in vitro da matéria orgânica, desaparecimento da fibra insolúvel de detergente neutro, energia metabolizável, fator de partição, rendimento de gás, ácidos graxos de cadeia curta, produção de biomassa de proteína microbiana. A fermentação in vitro simulando dietas de confinamento, determinou-se que a participação de enzimas fibrolíticas aumentou PG, e melhorou as características dos parâmetros cinéticos e perfil da fermentação, independente da combinação ou/não com outras enzimas. A fermentação in vitro simulando dietas de forragem, a participação de enzimas fibrolíticas aumentou PG, com melhorias nos parâmetros cinéticos e perfil da fermentação, com ou sem a combinação de outras enzimas. A inclusão apenas de enzimas fibrolíticas tem o maior potencial de otimizar a utilização de dieta de confinamento como também em forragens na alimentação de ruminantes.

Palavras-chave: amilolítica, confinamento, fibrolítica, forragem, proteolítica

\section{INTRODUCTION}

In feedlot animal production systems, the food supply is nutritionally balanced, to provide an optimum supply of nutrients (COLE et al., 2012). However, the maximization of the use of food at the ruminal level is currently of great interest with regards to animal production.

The rate and extent of degradation of the starch granules in corn, often the main constituent of diets, may be increased depending on its physical structure (McALLISTER et al., 1993; McALLISTER et al., 2006), and the method and intensity of its processing (PHILIPPEAU et al., 1999a, b; TAYLOR $\&$ ALLEN, 2005).

Another important point is that in feedlot diets, reduction of ruminal $\mathrm{pH}$ due to a higher intake of fermentable nutrients (OWENS et al., 1998) restricts the growth of microorganisms that digest fiber
(RUSSELL \& DOMBROWSKI, 1980; HOOVER et al., 1984). Under these conditions, lower forage digestibility may limit nutrient availability for ruminal microbial growth, and negatively affect the production of microbial digestive enzymes (ADESOGAN et al., 2014; MEALE et al., 2014).

Therefore, the use of exogenous enzyme preparations with different combinations of enzymatic activities could allow an improvement in ruminal kinetic parameters, in nutrient digestibility, and in the synthesis of crude microbial protein (ELGHANDOUR et al., 2013; GADO et al., 2009; GADO et al., 2011) under different dietary conditions, because their activity is not impaired in low $\mathrm{pH}$ conditions (MORGAVI et al., 2001).

The variability of the results obtained in previous studies (LEWIS et al., 1999; KUNG et al., 2002; WEISS et al., 2011), is due to factors such as the mode and duration of enzyme activity, the stability of the enzymes, enzymefood interactions, and the level of inclusion of the enzymes in the diet (ADESOGAN et al., 2014; MEALE et al., 2014). There is also a need for studies in tropical conditions, in order make sure that results obtained with exogenous enzymes included as food additives.

We hypothesized that different combinations of exogenous enzymes may increase the in vitro digestibility of dry matter $(\mathrm{DM})$, organic matter $(\mathrm{OM})$ and neutral detergent insoluble fiber (NDF), using feedlot and pasture diets. The objective of this study was to evaluate eight combinations of three exogenous enzyme preparations with fibrolytic, amylolytic and proteolytic activities on the gas production, kinetic parameters and fermentation profile, using in vitro fermentation with ruminal fluid using feedlot or forage diets. 


\section{MATERIALS AND METHODS}

Two experiments were performed to evaluate the effects of the exogenous enzymes under tropical conditions. In experiment $1 \mathrm{a}$ feedlot diet was used and for experiment 2 , the diet comprised only forage. The feedlot diet was formulated with a roughage:concentrate ratio of 20:80, composed of corn silage, ground corn, soybean meal, soybean hulls and a mineral mix (Table 1).

The diet from the pasture production system used Brachiaria brizantha cv. Marandu forage, the samples being obtained in the rain, and collected by manual grazing simulation in triplicate samples from five different places in the municipality of Santo Antônio do Leverger, Mato Grosso - Brazil. The average dry matter (DM, g/kg), organic matter (OM, g/kg DM), crude protein (CP, g/kg DM) and neutral detergent insoluble fiber (NDF, $\mathrm{g} / \mathrm{kg} \mathrm{DM}$ ) contents in samples of Brachiaria brizantha cv. Marandu were 285.1, 930.2,108.7 and 608.5 , respectively.

Table 1. Formulation and chemical composition of the feedlot diet

\begin{tabular}{lc}
\hline Ingredients, g/kg DM & Feedlot diet \\
\hline Corn silage & 200.0 \\
Ground corn & 540.0 \\
Soybean meal & 120.0 \\
Soybean hulls & 105.0 \\
Mineral mix 1 & 35.0 \\
\hline Chemical composition & \\
\hline DM, g/kg & 685.1 \\
OM, g/kg in DM & 941.4 \\
CP, g/kg in DM & 127.4 \\
NDF, g/kg in DM & 265.0 \\
\hline
\end{tabular}

1 Mineral mix - certified levels: calcium 198g; phosphorus 60g; sodium $117 \mathrm{~g}$; magnesium $5.1 \mathrm{~g}$; sulfur $12.6 \mathrm{~g}$; iodine $17.7 \mathrm{mg}$; iron $425 \mathrm{mg}$; selenium $10.4 \mathrm{mg}$; cobalt $80 \mathrm{mg}$; manganese $527 \mathrm{mg}$; fluorine $600 \mathrm{mg}$; copper $1000 \mathrm{mg}$ and zinc $3000 \mathrm{mg}$.
Eight combinations of the following enzyme preparations were evaluated: fibrolytic enzyme, FIB - Fibroyme; amilolytic enzyme, AMZ - Amaize; proteolytic enzyme, PRO - VEG PRO (All enzymes supplied by Alltech Inc., Nicholasville, KY). Based on previous studies the combinations were:

$\mathrm{CON}=$ control, diets without enzyme inclusion;

FAP $=$ Combination of fibrolytic (2.4 $\mathrm{mg} / \mathrm{mL})$, amylolytic $(0.10 \mathrm{mg} / \mathrm{mL})$ and proteolytic $(0.10 \mathrm{mg} / \mathrm{mL})$ enzyme;

$\mathrm{FA}=$ Combination of fibrolytic (2.4 $\mathrm{mg} / \mathrm{mL})$ and amylolytic $(0.10 \mathrm{mg} / \mathrm{mL})$ enzyme;

$\mathrm{FP}=$ Combination of fibrolytic (2.4 $\mathrm{mg} / \mathrm{mL})$ and proteolytic $(0.10 \mathrm{mg} / \mathrm{mL})$ enzyme;

$\mathrm{AP}=$ Combination of amylolytic $(0.10$ $\mathrm{mg} / \mathrm{mL})$ and proteolytic $(0.10 \mathrm{mg} / \mathrm{mL})$ enzyme;

FIB = Fibrolytic enzyme only (2.4 $\mathrm{mg} / \mathrm{mL}$ );

$\mathrm{AMZ}=$ Amylolytic enzyme only $(0.10$ $\mathrm{mg} / \mathrm{mL}$ );

PRO $=$ Proteolytic enzyme only $(0.10$ $\mathrm{mg} / \mathrm{mL}$ ).

The dosage of the enzyme compounds was determined according to the volume of liquid present in the medium $(\mathrm{mg} / \mathrm{mL}$ of incubated liquid) (TRICARICO et al., 2005).

In experiment 1 , using the feedlot diet, the ruminal inoculum was collected from two Santa Inês sheep (body weight $65 \pm 5 \mathrm{~kg}$ ) fitted with permanent ruminal cannula and fed with a total diet with a roughage:concentrate ratio of 20:80 ad libitum, adapted for 15 days. The animals were kept in individual covered stalls with eating and drinking containers.

In experiment 2, with a forage-only diet, the ruminal inoculum was collected from two Santa Inês sheep (of body weight $65 \pm 5 \mathrm{~kg}$ of Body Weight) fitted with permanent ruminal cannula. The 
animals were kept in paddocks with Brachiaria brizantha cv. Marandu forage and drinking containers.

In both experiments, the ruminal content of each animal was obtained in the morning ( $5 \mathrm{~h}$ a.m.), and filtered through four layers of cheesecloths before being placed in thermos bottles, without head-space, and sent to the Animal Nutrition Laboratory at "Universidade Federal de Mato Grosso".

To each flask (serum bottles of volume $125 \mathrm{~mL}$ ), $0.5 \mathrm{~g}$ of food from the appropriate production system were added along with the enzymes at their respective doses according to the combinations detailed above. Then, 40 $\mathrm{mL}$ of buffer solution was added to each flask with $10 \mathrm{~mL}$ of particle-free ruminal liquid (a proportion of 1:4 ruminal fluid:buffer (v/v)), according to the method of Goering \& Van Soest (1970). The flasks were immediately closed with rubber stoppers, sealed with aluminum washers and incubated at $39^{\circ} \mathrm{C}$ in a water bath with constant agitation.

A total of 81 serum bottles were used eight combinations of the enzymatic complexes incubated in triplicate for 96 $\mathrm{h}$, over three weeks, and three further control serum bottles containing only ruminal liquid and buffer solution in each experiment. The volume of gas produced was recorded after 1, 2, 3, 4, 5 $6,8,10,12,18,24,30,36,42,48,60$, 72 and 96 hours of incubation, using the semiautomatic reading technique described by Theodorou et al. (1994) and Maurício et al. (1999). At the end of the incubation, the flasks were opened to read the $\mathrm{pH}$ (peagâmetro, $\mathrm{pH}$ METER TC-2, Tecnal), and the contents of each flask were filtered through quantitative filter paper (Whatman $\mathrm{n}^{0}$. 54, $11 \mathrm{~cm}$, retaining particles above 20-25 $\mu \mathrm{m}$ ). After filtering, the fermentation residues were oven dried at $105^{\circ} \mathrm{C}$ for $16 \mathrm{~h}$ to estimate the dry matter degradability (DMD, $\mathrm{mg} / \mathrm{g} \mathrm{DM}$ ).

To determine the digestibility of neutral detergent insoluble fiber, after the incubation, $40 \mathrm{~mL}$ per flask (MERTENS, 2002), of neutral detergent solution was added (VAN SOEST et al., 1991), and the flasks were autoclaved according to Pell \& Schofield (1993). The contents of each flask were then filtered through a filter crucible (porosity $\mathrm{n}^{\circ} .2,40-100 \mu \mathrm{m}$ size screen). After filtration, the NDF residues were oven dried at $105^{\circ} \mathrm{C}$ for $16 \mathrm{~h}$ to estimate the digestibility of neutral detergent insoluble fiber in vitro (NDFD, $\mathrm{mg} / \mathrm{g}$ DM).

Initially, food samples were dried via forced ventilation $\left(55^{\circ} \mathrm{C}\right.$ for $\left.72 \mathrm{~h}\right)$, processed in a Willey type mill with a $1.0 \mathrm{~mm}$ size screen and stored for further determination of their chemical components and in vitro gas production. Chemical-bromatological analyses of the food samples were carried out in accordance with the procedures of the AOAC (1990) for dry matter (DM, method no. 930.15), ash (method no. 924.05) and crude protein (CP, method no. 984.13). The NDF was determined by the method of Van Soest et al. (1991).

The minimum activity of the fibrolytic (xylanase activity of $583 \mathrm{U} / \mathrm{g}$ and cellulase activity of $163 \mathrm{U} / \mathrm{g}$ ), amilolytic $(\alpha$-amylase activity of $600 \mathrm{U} / \mathrm{g}$ ) and proteolytic enzymes (protease activity of $7.500 \mathrm{U} / \mathrm{g}$ and cellulase activity of 45 $\mathrm{U} / \mathrm{g}$ ) were checked prior to the experiments according to the methodologies of Colombatto \& Beauchemin (2003), Tricarico et al. (2008) and the Food Chemicals Codex (2010).

The kinetic parameters of gas production $(\mathrm{mL} / \mathrm{g}$ of $\mathrm{DM})$ using the 
feedlot diet were estimated using PROC NLIN in SAS version 9.3 (2001) according to the model proposed by Schofield et al. (1994):

$$
V_{t}=V_{1 f} /\left(1+\exp \left(2-4_{1}^{* *}(T-L)\right)\right)+V_{2 f} /\left(1+\exp \left(2-4_{2}^{* *}(T-L)\right)\right)
$$

where $V_{t}$ is the volume accumulated in time $t ; V_{1 f}$ is the volume of gas from the fraction of rapid degradation (NFC); $k_{1}$ is the rate of $\mathrm{V}_{1 \mathrm{f}}\left(\mathrm{h}^{-1}\right)$; $\mathrm{L}$ is the latency; and $\mathrm{T}$ is the time (h); $\mathrm{V}_{2 \mathrm{f}}$ is the gas volume of the fraction of slow degradation $\left(\mathrm{B}_{2}\right) ; k_{2}$ is the rate of $\mathrm{V}_{2 \mathrm{f}}\left(\mathrm{h}^{-}\right.$ $\left.{ }^{1}\right)$. To make adjustments, the iterative process of the Marquadt algorithm was used.

The kinetic parameters of gas production $(\mathrm{mL} / \mathrm{g} \mathrm{DM})$ of the forageonly diet were estimated using PROC NLIN in SAS (version 9.3) according to the model proposed by Lavrencic et al. (1997):

$$
y=a x \exp (-\exp (1+K d x(L-T)))
$$

where $a$ is the asymptotic gas production $(\mathrm{mL}) ; b$ is the rate of fractional degradation $\left(\mathrm{h}^{-1}\right)$; and $L$ is the lag time (h).
The metabolizable energy (ME, $\mathrm{MJ} \mathrm{kg}^{-1}$ $\mathrm{DM})$ and in vitro digestibility of organic matter (OMD, g kg $\left.\mathrm{kg}^{-1} \mathrm{OM}\right)$ were estimated according to Menke et al. (1979):

$$
\begin{gathered}
M E=2.20+0.136 G P\left(\frac{m L}{0.2} g D M\right)+0.057 C P\left(\frac{m g}{0.2} g D M\right) \\
O M D=148.8+8.89 G P+4.5 G P(m g / 0.2 g D M)+0.651 \operatorname{ash}(m g / 0.2 g D M)
\end{gathered}
$$

where GP is the gas production in $\mathrm{mL}$ from $200 \mathrm{mg}$ of dry sample incubated for $24 \mathrm{~h}$.

The partition factor at $96 \mathrm{~h}$ of incubation $\left(\mathrm{PF}_{96} ; \mathrm{mg}\right.$ DMD:mL gas, measures fermentation efficiency) was calculated using the in vitro $\mathrm{DM}$ digestibility ratio (DMD, mg) per volume (mL) of GP at 96h (i.e., $\mathrm{DMD} /$ gas production $\left(\mathrm{GP}_{96}\right)$ ), according to Blümmel et al. (1997).

The gas yield $\left(\mathrm{GY}_{24}\right)$ was calculated with the gas volume (gas $\mathrm{mL} / \mathrm{g}$ of DM) produced after $24 \mathrm{~h}$ incubation divided by the value of DMD (g) according to Salem et al. (2014):

$$
\text { gas yield }\left(G Y_{24}\right)=G P(m L / g D M) / D M D(g)
$$

The concentration of short chain fatty acid (SCFA, mmol/g MS) was calculated according to Getachew et al. (2002):

$$
\text { SCFA }(\mathrm{mmol} / 0.2 \mathrm{~g} \mathrm{DM})=0.0222 \text { GP }-0.00425
$$


where GP is the production of gas at 24 $\mathrm{h}(\mathrm{mL} / \mathrm{g} \mathrm{DM})$.

The production of microbial CP biomass (MCP, $\mathrm{mg} / \mathrm{g} \quad \mathrm{DM})$ was calculated according to Blümmel et al. (1997):

$$
M C P(m g / g D M)=D M D(m g)-(G P \times 2.2 m g / m L)
$$

Where GP at $24 \mathrm{~h}$ is the production of liquid gas $(\mathrm{mL} / \mathrm{g}$ of $\mathrm{DM})$, and 2.2 $\mathrm{mg} / \mathrm{mL}$ is a stoichiometric factor that expresses the mass in $\mathrm{mg}$ of $\mathrm{C}, \mathrm{H}$ and $\mathrm{S}$ necessary for the production of the SCFA associated with the production of $1 \mathrm{~mL}$ of gas.

In vitro gas production data and fermentation parameters were analyzed using a completely randomized design using the PROC MIXED model in SAS (version 9.3.). The model used was:

$$
Y_{i j}=\mu+C O M B_{i}+\varepsilon_{i j}
$$

where $Y_{i j}$ is the dependent variable, $\mu$ is the overall mean, $\mathrm{COMB}_{i}$ is the effect of the combinations between the enzymes, and $\mathrm{E}_{\mathrm{ij}}$ is a residual error term. The combinations of enzymes were considered as fixed effects. Before the statistical analysis, we obtained the mean of the data within each week, which was used as an experimental unit (UDEN et al., 2012). The option LSMEANS was used to generate individual means for each treatment. For the combinations of enzymes comparisons were made using Fisher's Minimum Difference. In statistical analyses, the significance level was $\mathrm{P}<0.05$.

\section{RESULTS AND DISCUSSION}

For the feedlot diet, the fibrolytic enzymes decreased $(\mathrm{P}<0.05)$ latency; however, there was no effect of enzyme combinations on the degradation rates, $\mathrm{K}_{1} \quad(\mathrm{P}>0.05)$ and $\mathrm{K}_{2}(\mathrm{P}>0.05)$, or the volume of gas production from the rapid and slow degradation fractions, $V_{1 f}$ $(\mathrm{P}>0.05)$ and $\mathrm{V}_{2 \mathrm{f}}(\mathrm{P}>0.05)$ (Table 2). Considering the accumulated gas production (GP), the addition of fibrolytic enzymes and their combinations resulted in higher GP $(\mathrm{P}<0.05)$ at all time points (Table 2$)$.

The use of fibrolytic enzymes and their enzymatic combinations resulted in higher values for dry matter degradability (DMD) $(\mathrm{P}<0,05)$, organic matter digestibility (OMD) $(\mathrm{P}<0.05)$, metabolizable energy (ME) $(\mathrm{P}<0.05)$, and short-chain fatty acids (SCFA) $(\mathrm{P}<0.05)$, and lower values for the $6 \mathrm{~h}$ partition factor 9 (PF96) $(\mathrm{P}<0.05)$, but did not change the $\mathrm{pH}(\mathrm{P}>0.05)$, gas yield at $24 \mathrm{~h}(\mathrm{GY} 24)(\mathrm{P}>0.05)$, or the production of microbial $\mathrm{CP}$ biomass (MCP) $(\mathrm{P}>0.05)$ (Table 3).

Addition of the exogenous enzymes with fibrolytic activity (FIB) produced better results than the other enzymes (amylolytic and proteolytic) on the parameters evaluated, and no combination was more effective than using FIB alone.

Although the feedlot diet has a low proportion of fiber, the FIB enzyme mixture has a broad spectrum of action, and can increase the digestibility of the non-fibrous fraction in grain-rich diets as a result of increased hydrolytic capacity in the ruminal liquid (BEAUCHEMIN et al., 1999; BEAUCHEMIN et al., 2004), or can even assist with breaking the pericarp 
barrier in cereal grains (MCALLISTER et al., 2006). In addition, there is a possible synergistic relationship between exogenous enzymes and ruminal microbiota (NSEREKO et al., 2002), as well an increase in bacterial fixation (ELGHANDOUR et al., 2013).

Table 2. Ruminal kinetic parameters and cumulative gas production after $96 \mathrm{~h}$ of incubation as affected by combinations of exogenous enzymes $(\mathrm{mg} / \mathrm{mL})$ using the feedlot diet

\begin{tabular}{lccccccccccc}
\hline \multirow{2}{*}{ Comb. ${ }^{1}$} & \multicolumn{4}{c}{ Parameters of gas production ${ }^{2}$} & \multicolumn{4}{c}{ in vitro gas production (mL/g DM) } \\
\cline { 2 - 12 } & $V_{l f}$ & $k_{1}$ & $L$ & $V_{2 f}$ & $k_{1}$ & GP6 & GP12 & GP24 & GP48 & GP72 & GP96 \\
\hline CON & 170.4 & 0.075 & $2.613^{\mathrm{a}}$ & 115.8 & 0.018 & $69.9^{\mathrm{b}}$ & $138.7^{\mathrm{b}}$ & $215.5^{\mathrm{b}}$ & $257.7^{\mathrm{b}}$ & $279.5^{\mathrm{b}}$ & $286.2^{\mathrm{b}}$ \\
FAP & 190.2 & 0.079 & $1.325^{\mathrm{cd}}$ & 154.2 & 0.021 & $102.5^{\mathrm{a}}$ & $183.4^{\mathrm{a}}$ & $266.6^{\mathrm{a}}$ & $319.8^{\mathrm{a}}$ & $340.7^{\mathrm{a}}$ & $344.4^{\mathrm{a}}$ \\
FA & 190.0 & 0.081 & $1.164^{\mathrm{d}}$ & 153.8 & 0.020 & $106.1^{\mathrm{a}}$ & $187.5^{\mathrm{a}}$ & $265.5^{\mathrm{a}}$ & $318.3^{\mathrm{a}}$ & $339.7^{\mathrm{a}}$ & $343.8^{\mathrm{a}}$ \\
FP & 188.0 & 0.080 & $1.086^{\mathrm{d}}$ & 154.6 & 0.020 & $106.0^{\mathrm{a}}$ & $186.0^{\mathrm{a}}$ & $264.3^{\mathrm{a}}$ & $317.3^{\mathrm{a}}$ & $338.9^{\mathrm{a}}$ & $343.2^{\mathrm{a}}$ \\
AP & 162.4 & 0.076 & $2.062^{\mathrm{ab}}$ & 122.0 & 0.018 & $74.3^{\mathrm{b}}$ & $141.1^{\mathrm{b}}$ & $212.0^{\mathrm{b}}$ & $255.5^{\mathrm{b}}$ & $277.6^{\mathrm{b}}$ & $284.4^{\mathrm{b}}$ \\
FIB & 209.2 & 0.075 & $0.803^{\mathrm{d}}$ & 140.4 & 0.019 & $111.2^{\mathrm{a}}$ & $194.9^{\mathrm{a}}$ & $275.9^{\mathrm{a}}$ & $324.1^{\mathrm{a}}$ & $344.9^{\mathrm{a}}$ & $345.6^{\mathrm{a}}$ \\
AMZ & 170.0 & 0.075 & $1.803^{\mathrm{bc}}$ & 119.0 & 0.017 & $78.5^{\mathrm{b}}$ & $146.8^{\mathrm{b}}$ & $217.6^{\mathrm{b}}$ & $259.5^{\mathrm{b}}$ & $281.9^{\mathrm{b}}$ & $289.2^{\mathrm{b}}$ \\
PRO & 168.2 & 0.074 & $1.847^{\mathrm{b}}$ & 120.2 & 0.018 & $77.3^{\mathrm{b}}$ & $145.0^{\mathrm{b}}$ & $217.4^{\mathrm{b}}$ & $260.1^{\mathrm{b}}$ & $281.9^{\mathrm{b}}$ & $288.4^{\mathrm{b}}$ \\
SEM & 22.56 & 0.008 & 0.169 & 21.69 & 0.002 & 5.19 & 6.89 & 10.53 & 7.67 & 6.87 & 6.32 \\
P value & 0.543 & 0.972 & $<0.001$ & 0.712 & 0.644 & $<0.01$ & $<0.01$ & 0.01 & $<0.01$ & $<0.01$ & $<0.01$ \\
\hline
\end{tabular}

Values followed by the same lowercase letter within one column not differ according to the Fisher LSD test, where $(\mathrm{P}<0.05)$ for the type I error. SEM, standard error of the mean; ${ }^{1} \mathrm{CON}$ is control $(0 \mathrm{mg} / \mathrm{mL})$; FIB, AMZ and PRO are exogenous fibrolytic $(2.4 \mathrm{mg} / \mathrm{mL}$ incubated liquid), amylolytic $(0.10 \mathrm{mg} / \mathrm{mL}$ incubated liquid) and proteolytic enzymes $(0.10 \mathrm{mg} / \mathrm{mL}$ incubated liquid), respectively; and FAP $(\mathrm{FIB}+\mathrm{AMZ}+\mathrm{PRO}), \quad \mathrm{FA}(\mathrm{FIB}+\mathrm{AMZ}), \quad \mathrm{FP}(\mathrm{FIB}+\mathrm{PRO}), \quad \mathrm{AP}(\mathrm{AMZ}+\mathrm{PRO})$, are their respective combinations; ${ }^{2} \mathrm{~V}_{1 \mathrm{f}}$ is the volume of gas from the fraction of rapid degradation (NFC); $k_{1}$ is the rate of $\mathrm{V}_{1 \mathrm{f}}\left(\mathrm{h}^{-1}\right)$; $\mathrm{L}$ is the latency, and $\mathrm{T}$ is the time $(\mathrm{h}) ; \mathrm{V}_{2 \mathrm{f}}$ is the gas volume of the fraction of slow degradation $\left(\mathrm{B}_{2}\right) ; k_{2}$ is the rate of $\mathrm{V}_{2 \mathrm{f}}\left(\mathrm{h}^{-1}\right)$.

Table 3. In vitro rumen fermentation profiles influenced by combinations of exogenous enzymes $(\mathrm{mg} / \mathrm{mL})$, on feedlot $\operatorname{diet}^{1}$

\begin{tabular}{lcccccccc}
\hline Combinations $^{2}$ & $\mathrm{pH}$ & DMD & OMD & ME & PF96 & GY24 & SCFA & MCP \\
\hline COM & 6.51 & $771^{\mathrm{c}}$ & $0.652^{\mathrm{b}}$ & $9.5^{\mathrm{b}}$ & $2.7^{\mathrm{ab}}$ & 302 & $4.76^{\mathrm{b}}$ & 300 \\
FAP & 6.46 & $866^{\mathrm{a}}$ & $0.745^{\mathrm{a}}$ & $10.9^{\mathrm{a}}$ & $2.5^{\mathrm{cd}}$ & 259 & $5.91^{\mathrm{a}}$ & 279 \\
FA & 6.47 & $859^{\mathrm{ab}}$ & $0.743^{\mathrm{a}}$ & $10.9^{\mathrm{a}}$ & $2.5^{\mathrm{d}}$ & 262 & $5.89^{\mathrm{a}}$ & 275 \\
FP & 6.47 & $850^{\mathrm{ab}}$ & $0.741^{\mathrm{a}}$ & $10.8^{\mathrm{a}}$ & $2.4^{\mathrm{d}}$ & 263 & $5.86^{\mathrm{a}}$ & 269 \\
AP & 6.54 & $825^{\mathrm{b}}$ & $0.648^{\mathrm{b}}$ & $9.4^{\mathrm{b}}$ & $2.9^{\mathrm{a}}$ & 271 & $4.70^{\mathrm{b}}$ & 358 \\
FIB & 6.46 & $867^{\mathrm{a}}$ & $0.761^{\mathrm{a}}$ & $11.1^{\mathrm{a}}$ & $2.5^{\mathrm{d}}$ & 264 & $6.12^{\mathrm{a}}$ & 261 \\
AMZ & 6.54 & $818^{\mathrm{b}}$ & $0.658^{\mathrm{b}}$ & $9.6^{\mathrm{b}}$ & $2.8^{\mathrm{a}}$ & 284 & $4.83^{\mathrm{b}}$ & 339 \\
PRO & 6.54 & $773^{\mathrm{c}}$ & $0.659^{\mathrm{b}}$ & $9.6^{\mathrm{b}}$ & $2.7^{\mathrm{bc}}$ & 303 & $4.83^{\mathrm{b}}$ & 294 \\
SEM & 0.04 & 11.65 & 0.019 & 0.29 & 0.059 & 13.63 & 0.23 & 25.54 \\
P value & 0.416 & $<0.001$ & $<0.001$ & 0.001 & $<0.001$ & 0.051 & 0.001 & 0.172 \\
\hline
\end{tabular}

Values followed by the same lowercase letter within one column not differ according to the Fisher LSD test, where $(\mathrm{P}<0.05)$ for the type I error. SEM, standard error of the mean. ${ }^{1} \mathrm{DMD}$ is in vitro dry matter degradability (mg/g DM); OMD is in vitro organic matter degradability (g/g DM incubated until 24h); ME is metabolizable energy (MJ/kg DM); PF96 is the partitioning factor at $96 \mathrm{~h}$ of incubation (mg DMD:mL gas); GY24 is the gas yield at $24 \mathrm{~h}(\mathrm{~mL}$ gas/g DMD); SCFA is short chain fatty acids (mmol/g $\mathrm{DM})$; $\mathrm{MCP}$ is microbial CP production $(\mathrm{mg} / \mathrm{g} \mathrm{DM}) .{ }^{2} \mathrm{CON}$ is control $(0 \mathrm{mg} / \mathrm{mL})$; FIB, AMZ and PRO are exogenous fibrolytic $(2.4 \mathrm{mg} / \mathrm{mL}$ incubated liquid), amylolytic $(0.10 \mathrm{mg} / \mathrm{mL}$ incubated liquid) and proteolytic enzymes $(0.10 \mathrm{mg} / \mathrm{mL}$ incubated liquid), respectively; and FAP (FIB+AMZ+PRO), FA $(\mathrm{FIB}+\mathrm{AMZ}), \mathrm{FP}(\mathrm{FIB}+\mathrm{PRO})$, and $\mathrm{AP}(\mathrm{AMZ}+\mathrm{PRO})$ are their respective combinations. 
In the feedlot conditions, although there is a greater proportion of corn in the diet, the amylolytic enzyme was not effective in increasing the dry matter digestibility of the diet. This may reflect a lack of breakdown of the protein matrix that surrounds the starch, causing a lower efficiency of enzymatic action (McALLISTER et al., 2006).

There is no clear reason for the lack of effect for proteolytic enzymes, alone or in combination. According to Beauchemin et al. (2004) and Adesogan (2005) several factors may interfere with the effectiveness of the action of exogenous enzymes, including differences in enzyme activity, application rate and composition; in the mode and time of enzymatic contact; in ruminal activity in vitro and in enzyme stability in this environment; as well as in the enzyme-food specificity.
Combinations of exogenous enzymes can be advantageous, as a wide variety of substrates can be targeted with a single product (McALLISTER et al., 2001). However, in the present study, the best results were achieved in the presence of the fibrolytic enzymes alone, the combinations proving to be unsuitable for the feedlot diet.

For the forage-only diet, using the enzyme combinations, there was an increase in the asymptotic gas production $(\mathrm{P}<0.05)$ when the fibrolytic enzyme was included, reducing the lag time $(\mathrm{P}<0.05)$, without changing the rates of fractional degradation $(\mathrm{P}>0.05)$ (Table 4). However, with regard to the accumulated gas production, enzymatic associations containing fibrolytic enzymes had higher GP $(\mathrm{P}<0.05)$ at all times (Table 4).

Table 4. Ruminal kinetic parameters and cumulative gas production after $96 \mathrm{~h}$ of incubation as affected by combinations of exogenous enzymes $(\mathrm{mg} / \mathrm{mL})$ using the forage-only diet

\begin{tabular}{|c|c|c|c|c|c|c|c|c|c|}
\hline \multirow{2}{*}{ Comb. ${ }^{1}$} & \multicolumn{3}{|c|}{${ }^{2}$ Parameters of gas production } & \multicolumn{6}{|c|}{ in vitro gas production $(\mathrm{mL} / \mathrm{g} \mathrm{DM})$} \\
\hline & $A$ & $B$ & $L$ & GP6 & GP12 & GP24 & GP48 & GP72 & GP96 \\
\hline $\mathrm{COM}$ & $252.9^{b}$ & 0.0501 & $7.85^{\mathrm{a}}$ & $17.7^{\mathrm{c}}$ & $25.6^{\mathrm{d}}$ & $70.1^{\mathrm{b}}$ & $177.4^{\mathrm{d}}$ & $225.5^{\mathrm{c}}$ & $243.5^{\mathrm{b}}$ \\
\hline FAP & $299.2^{\mathrm{a}}$ & 0.0464 & $1.23^{\mathrm{c}}$ & $39.3^{\mathrm{a}}$ & $57.3^{\mathrm{b}}$ & $110.3^{\mathrm{a}}$ & $220.5^{b}$ & $269.7^{\mathrm{a}}$ & $287.6^{\mathrm{a}}$ \\
\hline FA & $303.7^{\mathrm{a}}$ & 0.0473 & $0.91^{\mathrm{c}}$ & $41.6^{\mathrm{a}}$ & $60.3^{\mathrm{ab}}$ & $116.5^{\mathrm{a}}$ & $227.9^{\mathrm{ab}}$ & $275.5^{\mathrm{a}}$ & $292.5^{\mathrm{a}}$ \\
\hline FP & $304.3^{\mathrm{a}}$ & 0.0457 & $0.46^{\mathrm{c}}$ & $42.9^{\mathrm{a}}$ & $60.3^{\mathrm{ab}}$ & $14.2^{\mathrm{a}}$ & $224.6^{\mathrm{ab}}$ & $273.1^{\mathrm{a}}$ & $291.4^{\mathrm{a}}$ \\
\hline AP & $261.8^{\mathrm{b}}$ & 0.0483 & $5.32^{\mathrm{ab}}$ & $23.9^{\mathrm{bc}}$ & $32.8^{\mathrm{c}}$ & $79.9^{\mathrm{b}}$ & $187.6^{\mathrm{c}}$ & $233.8^{\mathrm{b}}$ & $250.6^{\mathrm{b}}$ \\
\hline FIB & $306.5^{\mathrm{a}}$ & 0.0463 & $0.03^{\mathrm{c}}$ & $45.2^{\mathrm{a}}$ & $63.2^{\mathrm{a}}$ & $118.6^{\mathrm{a}}$ & $229.8^{\mathrm{a}}$ & $276.7^{\mathrm{a}}$ & $294.5^{\mathrm{a}}$ \\
\hline AMZ & $260.4^{b}$ & 0.0468 & $4.55^{\mathrm{b}}$ & $25.7^{\mathrm{b}}$ & $34.5^{\mathrm{c}}$ & $79.8^{\mathrm{b}}$ & $185.9^{c}$ & $231.3^{b c}$ & $247.9^{b}$ \\
\hline PRO & $263.3^{\mathrm{b}}$ & 0.0466 & $4.49^{\mathrm{b}}$ & $26.0^{\mathrm{b}}$ & $34.7^{\mathrm{c}}$ & $80.5^{\mathrm{b}}$ & $187.3^{\mathrm{c}}$ & $233.0^{\mathrm{b}}$ & $250.5^{\mathrm{b}}$ \\
\hline SEM & 6.02 & 0.0029 & 0.83 & 2.14 & 1.48 & 3.72 & 2.70 & 2.43 & 3.00 \\
\hline$P$ value & $<0.01$ & 0.97 & $<0.01$ & $<0.01$ & $<0.01$ & $<0.01$ & $<0.01$ & $<0.01$ & $<0.01$ \\
\hline
\end{tabular}

Values followed by the same lowercase letter within one column not differ according to the Fisher LSD test, where $(\mathrm{P}<0.05)$ for the type I error. SEM, standard error of the mean; ${ }^{1} \mathrm{CON}$ is control $(0 \mathrm{mg} / \mathrm{mL})$; FIB, AMZ and PRO are exogenous fibrolytic $(2.4 \mathrm{mg} / \mathrm{mL}$ incubated liquid), amylolytic $(0.10 \mathrm{mg} / \mathrm{mL}$ incubated liquid) and proteolytic enzymes $(0.10 \mathrm{mg} / \mathrm{mL}$ incubated liquid), respectively, and FAP (FIB+AMZ+PRO), FA (FIB+AMZ), FP (FIB+PRO), and AP (AMZ+PRO), are their respective combinations; ${ }^{2} a$ is the asymptotic gas production $(\mathrm{mL} / \mathrm{g} \mathrm{DM}) ; b$ is the rate of gas production $\left(\mathrm{h}^{-1}\right) ; L$ is the lag time (h). 
The use of enzymatic combinations including fibrolytic enzymes resulted in higher values for organic matter digestibility (OMD) $(\mathrm{P}<0.05)$, neutral detergent insoluble fiber digestibility (NDFD) $(\mathrm{P}<0.05)$, metabolizable energy (ME) $(\mathrm{P}<0.05)$, gas yield after 24 hours (GY24) $(\mathrm{P}<0.05)$ and short-chain fatty acids (SCFA) $(\mathrm{P}<0.05)$, and lower values for the partition factor at 96 hours (PF96) $(\mathrm{P}<0.05)$ and microbial $\mathrm{CP}$ production
$(\mathrm{MCP})(\mathrm{P}<0.05)$ (Table 5). The enzyme combinations did not change the $\mathrm{pH}$ $(\mathrm{P}>0.05)$ or dry matter degradability (DMD) $(\mathrm{P}>0.05)$ (Table 5).

Exogenous enzymes with amylolytic (AMZ) and proteolytic activity (PRO) increased the production of microbial protein $(\mathrm{P}<0.05)$ compared with $\mathrm{FIB}$, but the values were not significantly different from the diet without addition of enzymes (Table 5).

Table 5. In vitro rumen fermentation profiles $^{1}$ influenced by combinations of exogenous enzymes $(\mathrm{mg} / \mathrm{mL})$ with the forage-only diet

\begin{tabular}{lccccccccc}
\hline Combinations $^{2}$ & pH & DMD & OMD & NDFD & ME & PF96 & GY24 & SCFA & MCP \\
\hline COM & 6.51 & 758 & $0.248^{\mathrm{b}}$ & $433^{\mathrm{b}}$ & $5.79^{\mathrm{b}}$ & $3.1^{\mathrm{a}}$ & $87^{\mathrm{b}}$ & $1.46^{\mathrm{b}}$ & $613^{\mathrm{a}}$ \\
FAP & 6.46 & 766 & $0.321^{\mathrm{a}}$ & $573^{\mathrm{a}}$ & $8.19^{\mathrm{a}}$ & $2.7^{\mathrm{c}}$ & $144^{\mathrm{a}}$ & $2.44^{\mathrm{a}}$ & $524^{\mathrm{b}}$ \\
FA & 6.47 & 770 & $0.328^{\mathrm{a}}$ & $577^{\mathrm{a}}$ & $8.44^{\mathrm{a}}$ & $2.5^{\mathrm{d}}$ & $149^{\mathrm{a}}$ & $2.54^{\mathrm{a}}$ & $518^{\mathrm{b}}$ \\
FP & 6.48 & 768 & $0.324^{\mathrm{a}}$ & $577^{\mathrm{a}}$ & $8.28^{\mathrm{a}}$ & $2.6^{\mathrm{cd}}$ & $146^{\mathrm{a}}$ & $2.48^{\mathrm{a}}$ & $522^{\mathrm{b}}$ \\
AP & 6.54 & 753 & $0.264^{\mathrm{b}}$ & $456^{\mathrm{b}}$ & $6.34^{\mathrm{b}}$ & $3.0^{\mathrm{b}}$ & $101^{\mathrm{b}}$ & $1.69^{\mathrm{b}}$ & $586^{\mathrm{a}}$ \\
FIB & 6.46 & 766 & $0.331^{\mathrm{a}}$ & $525^{\mathrm{a}}$ & $8.53^{\mathrm{a}}$ & $2.6^{\mathrm{cd}}$ & $152^{\mathrm{a}}$ & $2.58^{\mathrm{a}}$ & $510^{\mathrm{b}}$ \\
AMZ & 6.54 & 762 & $0.264^{\mathrm{b}}$ & $449^{\mathrm{b}}$ & $6.31^{\mathrm{b}}$ & $3.1^{\mathrm{a}}$ & $100^{\mathrm{b}}$ & $1.68^{\mathrm{b}}$ & $596^{\mathrm{a}}$ \\
PRO & 6.54 & 770 & $0.264^{\mathrm{b}}$ & $453^{\mathrm{b}}$ & $6.32^{\mathrm{b}}$ & $3.1^{\mathrm{a}}$ & $99^{\mathrm{b}}$ & $1.68^{\mathrm{b}}$ & $604^{\mathrm{a}}$ \\
EPM & 0.034 & 5.14 & 0.0054 & 19.21 & 0.17 & 0.03 & 4.63 & 0.072 & 10.35 \\
P value & 0.367 & 0.330 & $<0.001$ & $<0.001$ & $<0.001$ & $<0.001$ & $<0.001$ & $<0.001$ & $<0.001$ \\
\hline
\end{tabular}

Values followed by the same lowercase letter within one column not differ according to the Fisher LSD test, where $(\mathrm{P}<0.05)$ for the type I error. SEM, standard error of the mean.

${ }^{1}$ DMD is in vitro dry matter degradability ( $\left.\mathrm{mg} / \mathrm{g} \mathrm{DM}\right)$; OMD is in vitro organic matter degradability (g/g DM incubated until 24h); NDFD is neutral detergent fiber digestibility (mg/g DM); ME is metabolizable energy (MJ/kg DM); PF96 is the partitioning factor at $96 \mathrm{~h}$ of incubation (mg DMD:mL gas); GY24 is gas yield at $24 \mathrm{~h}$ (mL gas/g DMD); SCFA is short chain fatty acids (mmol/g DM); MCP is microbial CP production $(\mathrm{mg} / \mathrm{g} \mathrm{DM})$.

${ }^{2} \mathrm{CON}$ is control $(0 \mathrm{mg} / \mathrm{mL})$; FIB, AMZ and PRO are exogenous fibrolytic $(2.4 \mathrm{mg} / \mathrm{mL}$ incubated liquid), amylolytic $(0.10 \mathrm{mg} / \mathrm{mL}$ incubated liquid) and proteolytic enzymes $(0.10 \mathrm{mg} / \mathrm{mL}$ incubated liquid), respectively, and FAP (FIB+AMZ+PRO), FA (FIB+AMZ), FP (FIB+PRO), and AP (AMZ+PRO), are their respective combinations.

The FIB enzyme mix provided better results than the other enzymes in most of the evaluated parameters, and the combinations were no more effective than the use of FIB alone. The forageonly diet contains a higher proportion of fiber (608.5 g NDF/kg DM), composed of cellulose, hemicellulose and lignin, presenting a larger number of binding sites for exogenous fibrolytic enzymes that include cellulase (endoglucanase) and xylanase activities (MEALE et al., 2014).

The presence of FIB improved the digestibility of NDF in agreement with previous research reports that the addition of exogenous fibrolytic enzymes promotes an increase in a range of enzymes that digest fiber (DONG et al., 1999; HRISTOV et 
al.,1998a; b). this may promote a synergistic relationship with ruminal microbiota, positively affecting the bacterial fixation of the fermentative substrate (ELGHANDOUR et al., 2013), because a greater effectiveness of the digestion of the fibrous material is achieved because of association of particles with bacteria (CRAIG et al., 1987). In our study, there was a reduction in lag time, i.e., the microorganisms achieved more rapid adhesion to the fermentation substrate, an important factor for biofilm formation and initiation of microbial enzymatic actions on fibrous material (EDWARDS et al., 2007).

Another possible factor in the better performance with fibrolytic enzymes is that the $\mathrm{pH}$ value remained at levels $(>6.5)$ that favor greater activity of fibrolytic enzymes (ADESOGAN et al., 2014) in comparison with proteolytic and amylolytic exogenous enzymes, which have their greatest activity at $\mathrm{pH}$ values below 5.0 (COLOMBATTO et al.. 2003; TRICARICO et al. 2008).

In summary, the inclusion of only fibrolytic enzymes $(2.4 \mathrm{mg} / \mathrm{mL}$ incubated liquid) has the greatest potential to optimize the use of both the feedlot diet and the forage-only diet in ruminants.

\section{ACKNOWLEDGMENTS}

The authors would like to thank CAPES (Coordenação de Aperfeiçoamento de Pessoal de Nivel Superior) for financial support, and the Sector of Nutrition of Beef Cattle in Pasture (Universidade Federal de Mato Grosso) and the Laboratory of the Animal Nutrition (Universidade Federal de Mato Grosso).

\section{REFERENCES}

ADESOGAN, A.T.; MA, Z.X.; ROMERO, J.J.; ARRIOLA, K.G. Ruminant Nutrition Symposium: Improving cell wall digestion and animal performance with fibrolytic enzymes.

Journal of Animal Science, v.92, p.1317-1330, 2014.

ASSOCIATION OF OFFICIAL ANALYTICAL CHEMISTS - AOAC. Official Methods of Analysis. $15^{\text {th }}$ ed. Arlington, 1990.

BEAUCHEMIN, K.A.; COLOMBATTO, D.; MORGAVI, D.P.; YANG, W.Z.; RODE, L.M. Mode of action of exogenous cell wall degrading enzymes for ruminants. Canadian Journal of Animal Science, v.84, p.13-22, 2004.

BEAUCHEMIN, K.A.; YANG, W.Z.; RODE, L. M. Effects of grain source and enzyme additive on site and extent of nutrient digestion in dairy cows. Journal of Dairy Science, v.82, p.378-390, 1999.

BLÜMMEL, M.; STEINGSS, H.; BECKER, K. The relationship between in vitro gas production, in vitro microbial biomass yield and $15 \mathrm{~N}$ incorporation and its implications for the prediction of voluntary feed intake of roughages. British Journal of Nutrition, v.77, p.911-921, 1997.

COLE, N.A.; TODD, R.W.; HALES, K.E.; PARKER, D.B.; BROWN, M.S.; MACDONALD, J.C. Nutritional management of feedlot cattle to optimize performance and minimize environmental impact. In: International SYMPOSIUM OF BEEF CATTLE PRODUCTION, 4, 2012, Viçosa, MG. Proceedings... Viçosa, MG, 2012. p.1-50. 
COLOMBATTO, D.; BEAUCHEMIN, K.A. A proposed methodology to standardize the determination of enzymatic activities present in enzyme additives used in ruminant diets.

Canadian Journal of Animal Science, v.83, p.559-568, 2003.

COLOMBATTO, D.; HERVÁS, G.; YANG, W.Z.; BEAUCHEMIN, K.A. Effects of enzyme supplementation of a total mixed ration on microbial fermentation in continuous culture, maintained at high and low $\mathrm{pH}$. Journal of Animal Science, v.81, p.2617-2627, 2003.

CRAIG, W.M.; BRODERICK, G.A.; RICKER, D.B. Quantitation of microorganisms associated with the particulate phase of ruminal ingesta. Journal of Nutrition, v.117, p.56-62, 1987.

DONG, Y.; BAE, H.D.; MCALLISTER, T.A.; MATHISON, G.W; CHENG, K.-J. The effect of exogenous fibrolytic enzymes, $\alpha$-bromoethanesulfonate and monensin on digestibility of grass hay and methane production in the Rusitec. Canadian Journal of Animal Science, v.79, p.491-498, 1999.

EDWARDS, J.E.; HUWS, S.A.; KIM, E.J.; KINGSTON-SMITH, A.H.

Characterization of the dynamics of initial bacterial colonization of nonconserved forage in the bovine rumen. FEMS

Microbiology and Ecology, v.62, p.323335, 2007.

ELGHANDOUR, M.M.Y.; SALEMA, A.Z.M.; GONZALEZ-RONQUILLOA, M.; BÓRQUEZA, J.L.; GADOB, H.M.; ODONGOC, N.E.; PENUELASA, C.G. Effects of exogenous enzymes on in vitro gas production kinetics and ruminal fermentation of four fibrous feeds.

Animal Feed Science and Technology, v.179, p.46-53, 2013.
FOOD CHEMICALS CODEX. United States Pharmacopeial Convention. $7^{\text {th }}$ ed. Washington, DC: National Academy Press, 2010.776p.

GADO, H.M.; SALEM, A.Z.M.; ODONGO, N.E.; BORHAMI, B.E. Effect of exogenous enzymes ensiled with orange pulp on digestion, blood metabolites and growth performance in lambs. Animal Feed Science and Technology, v.165, p.131-136, 2011.

GADO, H.M.; SALEM, A.Z.M.; ROBINSON, P.H.; HASSAN, M. Influence of exogenous enzymes on nutrient digestibility, extent of ruminal fermentation as well as milk production and composition in dairy cows. Animal Feed Science and Technology, v.154, p.36-46, 2009.

GETACHEW, G.; MAKKAR, H.P.S.; BECKER, K. Tropical browses: contents of phenolic compounds, in vitro gas production and stoichiometric relationship between short chain fatty acid and in vitro gas production.

Journal of Agricultural Science, v.139, p.341-352, 2002.

GOERING, M.K.; VAN SOEST, P.J. Forage fiber analysis (apparatus, reagents, procedures and some applications). Agriculture Handbook, No. 379. Washington, DC: Agricultural Research Service / USDA, 1970.

HOOVER, W.H.; KINCAID, C.R.; VARGA, G.A.; THAYNE, W.V.; JUNKINS, L.L. Jr. Effects of solids and liquid flows of fermentation in continuous cultures. IV. $\mathrm{pH}$ and dilution rates. Journal of Animal Science, v.58, p.692-699, 1984. 
HRISTOV, A.N.; MCALLISTER, T.A.; CHENG, K.-J. Stability of exogenous polysaccharide-degrading enzyme in the rumen. Animal Feed Science and Technology, v.76, p.165-172, 1998a.

HRISTOV, A.N.; MCALLISTER, T.A.; CHENG, K.-J. Effect of dietary or abomasal supplementation of exogenous polysaccharide-degrading enzyme supplementation on rumen fermentation and nutrient digestibility.

Journal of Animal Science, v.76, p.3146-3156, 1998b.

KUNG, L. JR.; COHEN, M.A.; RODE, L.M.; TREACHER, R. J. The effect of fibrolytic EFEs sprayed onto forages and fed in a total mixed ration to lactating dairy cows. Journal of Dairy Science, v.85, p.2396-2402, 2002.

LAVRENCIC, A.; STEFANON, B.; SUSMEL, P. An evaluation of the Gompertz model in degradability studies of forage chemical components. Animal Science, v.64, p.423-431, 1997.

LEWIS, G.E.; SANCHEZ, W.K.; HUNT, C.W.; GUY, M.A.; PRITCHARD, G.T.; SWANSON, B.I.; TREACHER, R. J. Effect of direct-fed fibrolytic EFEs on the lactational performance of dairy cows. Journal of Dairy Science, v.82, p.611-617, 1999.

MAURÍCIO, R.M.; MOULD, F.L.; DHANOA, M.S.; OWEN, E.; CHANNA, K.S.; THEODOROU, M.K. A semi-automated in vitro gas production technique for ruminant feedstuff evaluation. Animal Feed Science and Technology, v.79, p.321330, 1999.

McALLISTER, T.A.; GIBB, D.J.; BEAUCHEMIN, K.A.; WANG, Y. Starch type, structure and ruminal digestion. In: CATTLE GRAIN
PROCESSING SYMPOSIUM, 2006, Tulsa, Oklahoma. Proceedings..., 2006. p.30-41. Aviable:

$<$ http://beefextension.com/proceedings/ca ttle_grains06/06-5.pdf $>$. Accessed: 15 May 2017.

McALLISTER, T.A.; PHILLIPPE, R.C.; RODE, L.M.; CHENG, K.-J. Effect of the protein matrix on the digestion of cereal grains by ruminal microorganisms. Journal of Animal Science, v.71, p.205-212, 1993.

McALLISTER, T.A.; HRISTOV, A.N.; BEAUCHEMIN, K.A.; RODE, L.M.; CHENG, K.J. Enzymes in ruminant diets. In: BEDFORD, M.R.; PARTRIDGE, G.G. Enzymes in Farm Animal Nutrition. Eds. CAB International, UK, p.273-298, 2001.

MEALE, S.J.; BEAUCHEMIN, K.A.; HRISTOV, A.N.; CHAVES, A.V.; MCALLISTER, T.A. BOARDINVITED REVIEW: Opportunities and challenges in using exogenous enzymes to improve ruminant production. Journal of Animal Science, v.92, p.427-442, 2014.

MENKE, K.H.; RAAB, L.; SALEWSKI, A.; STEINGASS, H.; FRITZ, D.;

SCHNEIDER, W. The estimation of the digestibility and metabolizable energy content of ruminant feeding stuffs from the gas production when they are incubated with rumen liquor in vitro. Journal of Agricultural Science, v.93, p.217-222, 1979.

MERTENS, D.R. Gravimetric determination of amylase-treated neutral detergent fiber in feeds with refluxing in beakers or crucibles: collaborative study. Journal of AOAC International, v.85, n.6, p.1217-1240, 2002. 
MORGAVI, D.P.; NEWBOLD, C.J.; BEEVER, D.E.; WALLACE, R.J.

Stability and stabilization of potential feed additive enzymes in rumen fluid. Enzyme and Microbial Technology, v.26, p.171-177, 2000.

OWENS, F.N.; SECRIST, D.S.; HILL, W.J.; GILL, D.R. Acidosis in cattle: a review. Journal of Animal Science, v.76, n.1, p.275-286, 1998.

PELL, A.N.; SCHOFIELD, P. Computerized monitoring of gas production to measure forage digestion in vitro. Journal of Dairy Science, v.76, n.9, p.1063-1073, 1993.

PHILIPPEAU, C.; DESCHAULT DE MONREDON, F. LE; MICHALETDOREAU, B. Relationship between ruminal starch degradation and the physical characteristics of corn grain. Journal of Animal Science, v.77, p.238-243, 1999a.

PHILIPPEAU, C.; MARTIN, C.; MICHALET-DOREAU, B. Influence of grain source on ruminal characteristics and rate, site, and extent of digestion in beef steers. Journal of Animal Science, v.77, p.1587-1596, 1999b.

RUSSELL, J.B.; DOMBROWSKI, D.B. Effect of $\mathrm{pH}$ on the efficiency of growth by pure cultures of rumen bacteria in continuous culture. Applied and Environmental Microbiology, v.39, p.606-610, 1980.

SALEM, A.Z.M.; KHOLIF, A.E.; OLIVARES, M.; ELGHANDOUR, M.M.Y.; MELLADO, M.; ARECE, J. Influence of S. babylonica extract on feed intake, growth performance and diet in vitro gas production profile in young lambs. Tropical Animal Health and Production, v.46, p.213-219, 2014.
SAS. The statistical analyze systems for windows: version 9.3. Cary, 19992001.

SCHOFIELD, P.; PITT, R.E.; PELL, A.N. Kinetics of fiber digestion from in vitro gas production. Journal of Animal Science, v.72, n.11, p.29802991, 1994.

TAYLOR, C.C.; ALLEN, M.S. Corn grain endosperm type and brown midrib 3 corn silage: Ruminal fermentation and $\mathrm{N}$ partitioning in lactating cows.

Journal of Dairy Science, v.88, p.1434-1442, 2005.

THEODOROU, M.K.; WILLIAMS, B.A.; DHANOA, M.S.; MCALLAN, A.B.; FRANCE, J. A simple gas production method using a pressure transducer to determine the fermentation kinetics of ruminant feeds. Animal Feed Science and Technology, v.48, p.185197, 1994.

TRICARICO, J.M; JOHNSTON, J.D.; DAWSON, K.A. Dietary supplementation of ruminant diets with an Aspergillus oryzae $\alpha$-amylase. Animal Feed Science and Technology, v.145, p.136-150, 2008.

TRICARICO, J.M.; JOHNSTON, J.D.; DAWSON, K.A.; HANSON, K.C.; MCLEOD, K.R.; HARMON, D.L. The effects of an Aspergillus oryzae extract containing alpha-amylase activity on ruminal fermentation and milk production in lactating Holstein cows. Animal Science, v.81, p.365-374, 2005.

UDEN, P.; ROBINSON, P.H.; MATEOS, G.G.; BLANK, R. Use of replicates in statistical analyses in papers submitted for publication in Animal Feed Science and Technology. Animal Feed Science and Technology, v.171, p.1115, 2012. 
VAN SOEST, P.J.; ROBERTSON, J.B.;

LEWIS, B.A. Methods for dietary fiber, neutral detergent fiber, and nonstarch

polysaccharides in relation to animal nutrition. Journal of Dairy Science, v.74, n.10, p.3583-3597, 1991.

WEISS, W.P.; STEINBERG, W.;

ENGSTROM, M.A. Milk production and nutrient digestibility by dairy cows when fed exogenous amylase with coarsely ground dry corn. Journal of Dairy Science, v.94, p.2492-2499, 2011.

Receipt date: $18 / 09 / 2017$

Approval date: 21/12/2017 